- Brasilia. "Marina does not negotiate on principles," she says.

Others go a step farther. "I think she is a little too radical," says Pedro Alves Vieira, a geologist at the State University of Goiás and environment secretary for the municipality of Goiás. Although Silva has hewed to the centre during the campaign, Vieira fears that she may be too focused on the environment, too religious and too rigid for the presidency.

But some of Silva's

"Ithinkit's major stances have time for a evolved. As environment change." minister, she opposed the introduction of genetically modified soya beans, but has since sought to mend fences with the powerful agribusiness industry - stressing that modern agriculture, practised legally, is not at odds with forest protection.

Her plan for sustainable development focuses on stemming Brazil's gradual shift toward fossil fuels: renewable energy fell from $95 \%$ of the nation's energy mix in the 1990 s to $78 \%$ in 2013 , according to her campaign. To reverse that trend, she is calling for the installation of solar panels on 1 million homes and the revitalization of the sugarcane ethanol sector, which has struggled to compete with heavily subsidized petrol. She is also pushing for sustainable forest concessions geared toward biomass energy.

By contrast, Rousseff has put more emphasis on dozens of large-scale hydroelectric dams that would increase development pressure on the Amazon rainforest. "We need more energy, but Brazil's current strategy is really based on big infrastructure," says Mercedes Bustamante, an ecologist at the University of Brasilia who spent two years at the science ministry under Rousseff. "I think it's time for a change."

Science policy has received little attention in the presidential campaign, although Silva has called for federal and private investments in research and development to expand from $1.1 \%$ of Brazil's gross domestic product to $2 \%$. The government's science spending has increased over the past decade, but researchers say that it has also been spread thin by new programmes.

Even if she takes the helm, Silva will have to tackle shifting political winds in Brasilia. In 2012, the nation's congress voted to weaken the country's forest law, and some lawmakers are now pushing to scale back protected lands to allow mining and energy development.

But Schwartzman warns against underestimating Silva's political skills should she win. "She and the others who worked with Chico Mendes in Acre really came through a crucible," he says. "In some ways, looking back on that experience, I'm not surprised that she is where she is now." -

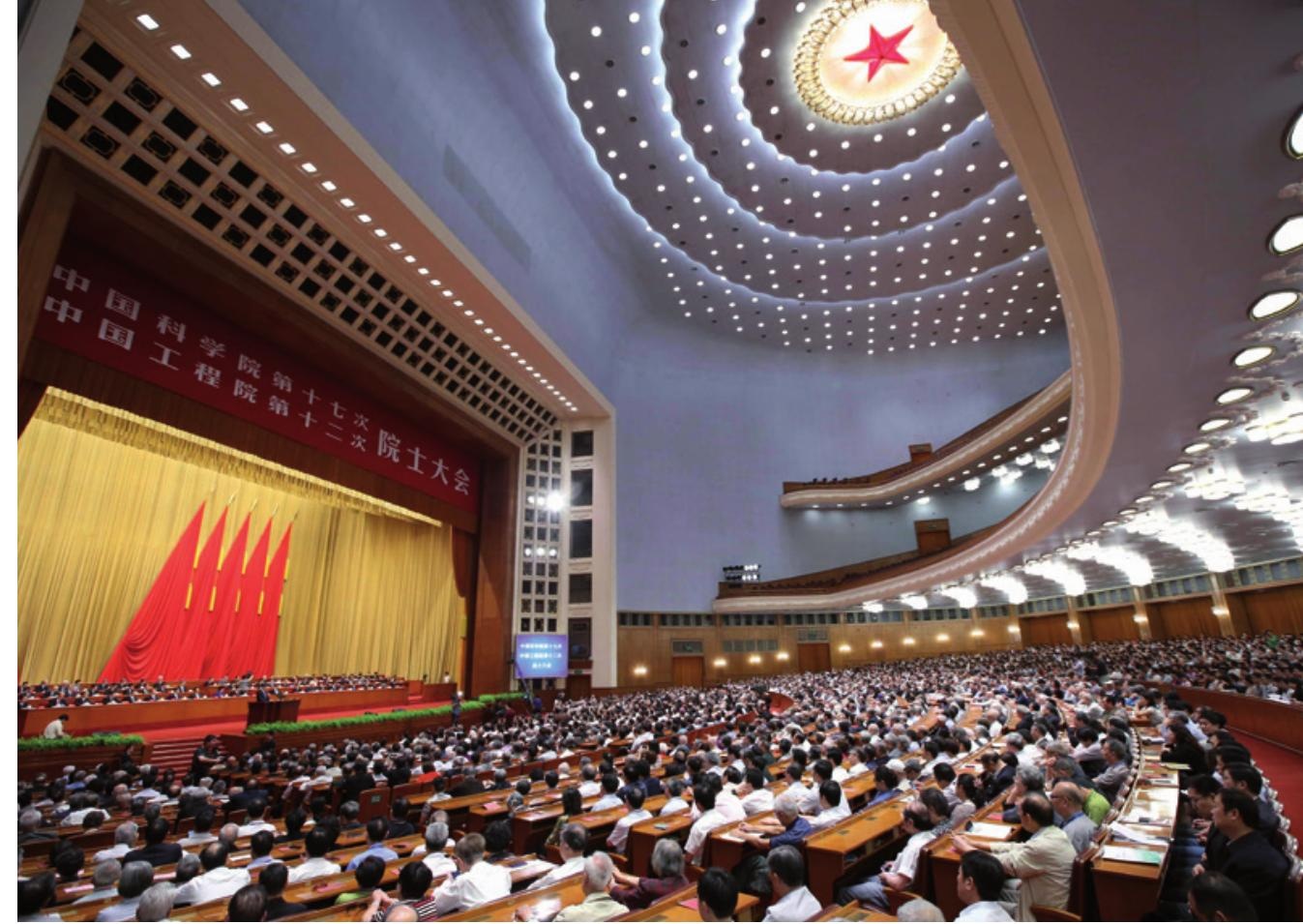

The Chinese Academy of Sciences, which employs 60,000 people, opens its 2014 congress in Beijing.

POLICY

\title{
Chinese science gets mass transformation
}

\section{Teamwork at centre of Chinese Academy of Sciences reform.}

\section{BY DAVID CYRANOSKI IN BEIJING}

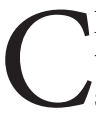
hange is coming to the institute that has been at the heart of China's scientific development since the communist state began. The Chinese Academy of Sciences (CAS) is making unprecedented structural reforms to foster collaboration and turbocharge research. Proponents say that the initiative will make China a world leader in areas from neuroscience to particle physics; detractors question whether modern China needs such a sprawling organization at all.

The CAS, headquartered in Beijing, employs 60,000 people, and has 104 research institutes and a budget of roughly 42 billion renminbi (US $\$ 6.8$ billion). Just under half comes from the government, to cover overhead costs and salaries; the rest comes from competitive government grants. It is "the biggest reform in the academy's history", CAS president Chunli Bai told Nature's news team in an interview on 22 September.

The initiative - which was designed by Bai - follows an appeal by Chinese president Xi Jinping in July 2013 for the CAS to become a world leader in science. Although China's spending on science now outpaces that of all countries except the United States, many agree that the country is not getting a good return on its investment, in terms of both basic-science breakthroughs and commercialization of those findings.

Some underperformance might result from low salaries for scientists - including those at the CAS, says Bai - who scramble to supplement their incomes with multiple grants. "Their research becomes very fragmented," he said.

Scientists also shy away from collaborations because co-authorship dilutes their achievements in the eyes of grant committees. At a conference in 2012, Bai discovered that researchers across 20 different CAS institutes were working on related projects, but often did not know each other - duplicating work and missing opportunities to share knowledge. He also notes that they had little interest in discussing applications with industry representatives.

To deal with these issues, Bai has grouped research into four categories, and promising CAS scientists are being selected to work together under them. They will see their salaries jump, relying on grants for only $30 \%$ of their income, rather than for $70 \%$. The idea is to encourage scientists to collaborate on fewer, large problems, rather than to churn out marginal advances in disparate projects that can be used to seek multiple grants. "Teamwork is the key word," says Mu-Ming Poo, director of the CAS Institute of Neuroscience in Shanghai.

The first category is devoted to establishing centres of excellence focused on basic science, 
and will target areas in which China has a chance to dominate. One team, for which Poo has already selected 40 researchers from 11 different CAS institutes, specializes in brain science - one goal is to produce a transgenic monkey model that could be useful for neurodegenerative-disease research.

Tandong Yao, director of the Institute of Tibetan Plateau Research in Beijing will head another centre focused on the seismically active plateau: his team wants to probe how the crust underneath deformed over time. Other centres will focus on particle physics, thorium-based molten-salt reactors, and quantum information. The plan is to take the count up to 20 centres by 2020 .

A second category will target areas with underdeveloped commercial potential, including microsatellites, marine information technology and drug development. A third category will establish collaborations around large-scale facilities: a synchrotron and a protein-science centre, for example, both in Shanghai, will be linked to make it easier to carry out high-precision protein studies and support academic and industry researchers, including some from abroad.

The fourth category, still in its design phase, will be devoted to initiatives that assist local development and sustainability. Its first will probably focus on work by the Institute of Mountain Hazards and Environment in Chengdu, which could help communities to prepare for natural disasters such as landslides.

But not everyone agrees that the changes tackle the key problems at the CAS. One Chinese university scientist, who is familiar with the reforms and did not want to be identified, says that the source of the problems is that the CAS hires too many young scientists who then go through little or no review, and essentially receive tenure without having to prove themselves. Bai counters that the opportunities offered by his initiatives will "encourage the underperformers to be better". He says that he has steered away from a US-style system in which underperformers can be fired: "It is a reform with Chinese characteristics."

Cong Cao, a science-policy specialist at the University of Nottingham, UK, says that the CAS is too big and unwieldy. "There's no organization in the world with so many functions," he says. He says that universities and individual research institutes, which are increasingly competing with the CAS for leading scientists, can offer a better management environment for scientists. "There probably is no reason for the CAS in China right now."

But Bai uses the same trait to justify the academy's existence: he argues that it allows the CAS to make wide contributions to China's development. "You have to understand the history," he says.

\section{Global Ebola response kicks into gear at last}

\section{US and UN mobilizations are welcome but overdue.}

\section{BY DECLAN BUTLER}

$\mathrm{T}$ The international community is responding to the Ebola outbreak - at long last. On 18 September, the United Nations Security Council adopted a resolution declaring the outbreak a "threat to international peace and security"; two days before, the United States had said that it will send 3,000 military personnel to West Africa and spend US\$750 million to support civilian efforts. Both moves are unprecedented for a disease outbreak and just what is needed, say experts. But there are fears that quelling the outbreak now will be more difficult than if it had been tackled earlier.

The Ebola outbreak was first detected in March, but only the humanitarian group Médecins Sans Frontières (MSF, or Doctors Without Borders) has so far deployed substantial relief in the affected region, which centres on Liberia, Sierra Leone and Guinea (for more, see nature.com/ebola). MSF has repeatedly demanded that the international community launch a major effort to tackle the outbreak.

The UN resolution calls on member states to respond urgently. As it was passed, UN secretary-general Ban Ki-moon launched the United Nations Mission for Ebola Emergency Response to deploy resources from UN agencies in coordination with efforts from member nations and donors. The mission's remit includes "stopping the outbreak, treating the infected, ensuring essential services, preserving stability and preventing further outbreaks," said Ban.

The United States plans to establish military-run command and control headquarters in Liberia and build 17 treatment centres of 100 beds each in the affected region. It hopes to recruit medical staff to run them, and train up to 500 health-care workers a week.

The public-health community tends to view military involvement "with suspicion and mistrust", says Adam Kamradt-Scott, a health-policy researcher at the University of Sydney in Australia. But he welcomes the US plan: "Military forces have unique skill sets that can assist civilian authorities." If the operation does help to counter Ebola, he adds, it could set a new precedent for responding to disease outbreaks of international concern.

Training forces in outbreak response will take time, warns Daniel Bausch, who studies infectious diseases at Tulane University in New Orleans, Louisiana, and is caring for people with Ebola in Sierra Leone. He adds that the situation is too dire for the United States alone to solve, and that other nations must step in, something that the UN resolution should catalyse. It was passed by unanimous vote and had a high number of member-state sponsors.

Jean-Clément Cabrol, director of operations for MSF in Geneva, Switzerland, says that both efforts are welcome, but that the situation has worsened in the past few weeks, so speed is key. Treatment centres in the three countries most affected are completely overwhelmed

"Military
forces have
unique skill
sets that can
assist civilian
authorities."
(see page 474). This is fuelling the spread of the disease, because centres are forced to send away infected people, who then contaminate others.

Conventional publichealth measures are no longer working, says Bausch. It has become next to impossible to detect and isolate those infected, and to monitor all the people they have been in contact with. He recommends focusing surveillance on areas next to affected zones to prevent further geographical spread of Ebola. He adds that international efforts will be effective only if they include training for health-care staff, for example in biosafety. Money and supplies are welcome, but by themselves, they are not enough. @ SEE EDITORIALP.459

\section{MORE ONLINE TOP NEWS}

- Population boom to last all century go.nature.com/xnsblj

- Male astronomers get bigger share of Hubble go.nature.com/v9e807

\section{IMAGE OF THE WEEK}

This map measures dust in the southern Galactic hemisphere. It suggests that

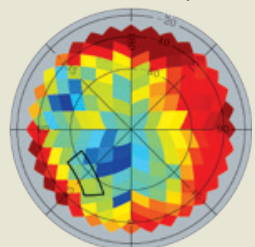
a signal of gravitational waves from the Big Bang previously observed in the black rectangle

could have been spurious. go.nature.com/ifalmw 